\title{
ANALISIS BIPLOT UNTUK MEMETAKAN SEKOLAH MENENGAH PERTAMA DI KABUPATEN KEPULAUAN SANGIHE BERDASARKAN EMPAT INDIKATOR STANDAR NASIONAL PENDIDIKAN
}

\author{
Jaqualine Tinungki ${ }^{1)}$, Djoni Hatidja ${ }^{2)}$, Hanny Komalig ${ }^{3)}$ \\ ${ }^{1)}$ Program Studi Matematika, FMIPA, UNSRAT, jaqualine tinungki@yahoo.com \\ ${ }^{2)}$ Program Studi Matematika, FMIPA, UNSRAT, dhatidja@yahoo.com \\ ${ }^{3)}$ Program Studi Matematika, FMIPA, UNSRAT, hanny07@yahoo.com
}

\begin{abstract}
Abstrak
Tujuan dari penelitian ini adalah untuk memetakan keunggulan dan kekurangan dari SMP-SMP di Kabupaten Kepulauan Sangihe berdasarkan empat indikator standar nasional pendidikan dengan menggunakan analisis biplot. Keempat indikator standar nasional tersebut merupakan peubah pada penelitian ini, standar tersebut yaitu standar pendidik dan tenaga kependidikan, standar sarana dan prasarana, standar pengelolaan dan standar pembiayaan pendidikan.

Data yang digunakan dalam penelitian adalah data sekunder yang diambil dari Dinas Pendidikan Nasional Kabupaten Kepulauan Sangihe dan dari sampel 12 SMP di Kabupaten Kepulauan Sangihe.Hasilnya menunjukan bahwa, sekolah-sekolah yang dikategorikan telah memiliki standar yang unggul terhadap keempat indikator standar nasional pendidikan adalah SMPN 1 Tahuna, SMPN 2 Tahuna, SMPN 3 Tahuna, SMPN 1 Tabukan Selatan tenggara dan SMPN 1 Tabukan Selatan. Sedangkan Sekolah sekolah yang dikategorikan memiliki standar yang kurang unggul terhadap keempat indikator standar nasional pendidikan adalah SMPN 1 Manganitu Selatan, SMPN 1 Tabukan Selatan Tengah, SMP Kristen Bellae, SMPN 6 Tabukan Utara, SMP Kristen Sawang Jauh, SMPN 6 Satap Manganitu dan SMPN 4 Tamako. Sekolah yang dikatakan unggul pada ju mlah dan kualifikasi guru, pustakawan, dan laboran.Ju mlah dan luas ruang perpustakaan, ju mlah dan luas ruang guru, serta ju mlah dan luas ruang tata usaha adalah SMP Negeri 1 Tahuna.
\end{abstract}

Kata kunci: Analisis Biplot, Seko lah Menengah Pertama, Standar Nasional Pendidikan

\section{BIPLOT ANALYSIS FOR MAPPING THE JUNIOR HIGH SCHOOL IN SANGIHE ISLA ND REGENCY BASED ON THE FOUR INDICATORS OF NATIONAL EDUCATION STA NDARD}

\begin{abstract}
The purpose of this research is to map the advantages and disadvantages of the Junior High Schools in the District of Sangihe Island based on four indicators of national education standard with Biplot Analysis. The fourth indicator the national standard is a variable in this research, the standard is the standard of teachers and education staff, facilities and infrastructure standards, management standards and the standards of education financing.

The data usedin this studyis asecondary data drawnfrom the National Education Service District of Sangihe Islands, and from 12 sample of Junior High Schools in distric of Sangihe Island.The results show that the schools are categorized has having a good standard on the four indicators of national education standards, SMPN 1 Tahuna, SMPN 2 Tahuna, SMPN 3 Tahuna, SMPN 1 Tabukan Selatan Tenggara and SMPN 1 Tabukan Selatan. While schools that are categorized poor standard of the fourth indicator of the national standard SMPN 1 Manganitu Selatan, SMPN1 Tabukan Selatan Tengah, SMP Kristen Bellae, SMPN 6 Tabukan Utara, SMP Kristen Sawang Jauh, SMPN 6 Satap Manganitu and SMPN 4 Tamako. Schools are said to be superior to the amount and qualifications of teachers, librarians, and the laboratory. The amount and a vast of library space, space is the administrative, as well as the amount of teachers living space SMPN 1 Tahuna.
\end{abstract}

Keywords:Biplot Analysis, Junior High School, National Education Standard

\section{Pendahuluan}

Sistem Pendidikan Nasional ditetapkan melalui undang-undang berupa Undang-undang Republik Indonesia Nomor 2 Tahun 1989 dan ditetapkan pada tanggal 27 Maret 1989.Sistem pendidikan nasional adalah satu keseluruhan yang terpadu dari semua satuan dan kegiatan 
pendidikan yang berkaitan satu dengan lainnya untuk mengusahakan tercapainya tujuan pendidikan nasional.

Untuk mewujudkan tujuan pendidikan nasional, pemerintah menetapkan 8 Standar Nasional Pendidikan Indonesia.LingkupStandar nasional pendidikan di Indonesia meliputi :Standar Kompetensi Kelulusan, Standar isi, Standar Proses, Standar Pendidik dan Tenaga Kependidikan, Standar Sarana dan Prasarana, Standar pengelolaan, Standar pembiayaan pendidikan dan Standar penilaian pendidikan. Dari 8 standar hanya empat yang dipakai dalam penelitian ini, keempat standar tersebut yaitu : standar pendidik dan tenaga kependidikan, standar sarana dan prasarana, standar pengelolaan dan standar pembiayaan pendidikan.

Penelitian terdahulu pernah dilakukan di Kabupaten Minahasa Tenggara dengan menggunakan analisis biplot. Pada penelitian yang dilakukan juga hanya menggunakan keempat standar nasional tersebut dari 8 komponen standar nasional pendidikan [1].

Analisis biplot merupakan salah satu bagian dari analisis peubah ganda (APG) yang dapat menyajikan secara simultan dalam bentuk gambar dua dimensi antara indikator standar pendidik dan tenaga kependidikan, standar sarana dan prasarana, standar pengelolaan pendidikan dan standar pembiayaan pendidikan (sebagai peubah) dengan SMP yang ada dikabupaten Kepulauan Sangihe(sebagai objek).

Tujuan dari penelitian ini yaitu untuk memetakan keunggulan dan kekurangan dari SMP-SMP di Kabupaten Kepulauan Sangihe berdasarkan empat indikator standar nasional pendidikan dengan menggunakan analis is biplot.

\section{Analis is Biplot}

Analisis biplot adalah teknik statistika deskriptif yang dapat disajikan secara visual guna menyajikan secara simultan $n$ objek pengamatan dan $p$ peubah dalam ruang bidang datar, sehingga ciri-ciri peubah dan objek pengamatan serta posisi relatif antar objek pengamatan dengan peubah dapat dianalisis [3].

Empat hal penting yang dapat dilihat pada biplot adalah

1. Hubungan (korelasi) antar peubah, dengan menggunakan biplot peubah akan digambarkan sebagai garis berarah. Dua peubah yang memiliki kore lasi positif tinggi akan digambarkan sebagai dua buah garis dengan arah yang sama, atau membentuk sudut yang sempit. Apabila dua peubah yang memiliki korelasi negatif tinggi akan digambarkan dalam bentuk dua garis yang arahnya berlawanan, atau membentuk sudut yang lebar (tumpul). Sedangkan dua buah peubah yang tidak berkorelasi akan digambarkan dalam bentuk dua garis yang mendekati $90^{\circ}$ (siku-siku)

2. Keragaman peubah, informasi ini digunakan untuk melihat apakah ada peubah tertentu yang nilainya hampir sama setiap objek ada yang sama besar dan ada juga yang sangat kecil. Dengan informasi ini, bisa diperkirakan pada peubah mana strategi tertentu harus ditingkatkan, serta sebaliknya.Dalam biplot, peubah dengan keragaman kecil digambarkan dengan vektor yang pendek, sedangkan peubah yang ragamnya besar digambarkan sebagai vektor yang panjang.

3. Kedekatan antar objek, informasi ini bisa dijadikan panduan objek mana yang memiliki kemiripan karakteristik dengan objek tertentu. Dalam biplot, dua objek dengan karakteristik sama akan digambarkan sebagai dua titik yang pos is inya berdekatan.

4. Nilai peubah pada suatu objek, informasi ini digunakan untuk melihat keunggulan dari setiap objek. Objek yang terletak searah dengan arah dari suatu peubah dikatakan bahwa pada objek tersebut nilainya diatas rata-rata. Sebaliknya jika objek lain terletak berlawanan dengan arah dari peubah tersebut maka objek tersebut memiliki nilai dekat dengan rata-rata [4].

Analisis biplot didasarkan pada penguraian nilai-nilai singular suatu matriks.Penguraian nilai singular dari suatu matriks merupakan teorema dasar yang banyak digunakan dalam perhitungan matriks.

Definisi dari SVD adalah suatu matriks $X$ yang merupakan matriks data dengan $n$ objek dan $p$ peubah diuraikan menjadi:

$X=U L A^{\prime}$

matriks $U$ dan $A$ adalah matriks berukuran $(n \times r)$ dan $\left(\begin{array}{lll}p & x & r\end{array}\right)$ sedemikian sehingga $U^{\prime} U=A^{\prime} A=$ $I_{r}$ (matriks identitas berdimensi r). $L$ adalah matriks diagonal berukuran $\left(\begin{array}{lll}r & x & r\end{array}\right)$ dengan elemen- 
elemennya adalah $\sqrt{\lambda_{1}} \geq \sqrt{\lambda_{2}} \geq \cdots \geq \sqrt{\lambda_{r}}$, dengan $\lambda_{\mathrm{i}}$ adalah akar ciri dari matriks $X^{\prime} X$. Unsur-unsur diagonal dari matriks $L$ disebut nilai singular matriks $X$.dan kolom- kolom matriks $A$ adalah vektor ciri dari $X^{\prime} X$ yang berpadanan dengan $\lambda$. Dengan penjabaran persamaan (1) menjadi[3]:

$X=U L A^{\prime}=U L^{\propto} L^{1-\propto} A^{\prime}$

Keakuratan dari biplot dalam menerangkan tingkat keragaman dari matriks data asal dirumuskan sebagai berikut [2].

Keterangan:

$$
\rho=\frac{\left(\lambda_{1}+\lambda_{2}\right)}{\sum_{k=1}^{p} \lambda_{k}}
$$

$$
\begin{aligned}
& \lambda_{1}=\text { akar ciri terbesar pertama } \\
& \lambda_{2}=\text { akar ciri terbesar kedua } \\
& \lambda_{k}=\text { akar ciri terbesar ke-k }
\end{aligned}
$$

Jika $\rho$ semakin mendekati nilai satu maka biplot yang diperoleh dari matriks pendekatan berpangkat dua akan memberikan penyajian yang semakin baik.

\section{Metodologi Penelitian}

Data yang digunakan dalam penelitian ini adalah data sekunder tahun 2014.Data diambil dari Dinas Pendidikan Nasional Kabupaten Kepulauan Sangihe dan dari Sekolah Menengah Pertama yang ada di Kabupaten Kepulauan Sangihe.

\subsection{Populasi dan Sampel}

Dari 54 Sekolah Menengah Pertama yang ada di Kabupaten Kepulauan Sangihe yang menjadi populasi sebanyak 48 sekolah, sekolah yang tidak termasuk pada populasi adalah sekolah yang berada diluar pulau besar. Pengambilan jumlah sampel yang digunakan yaitu dengan simple random sampling (sampling acak sederhana). Teknik menentukan ukuran sampel dari populasi dalam penelitian ini yaitu teknik slovin.[5] dengan Rumus slovin yaitu:

$n=\frac{N}{N e^{2}+1}$

Keterangan:

$n=$ besarnya ukuran sampel

$N=$ besaran populasi

$e^{2}=$ presisi yang diinginkan untuk diambil ' $10 \%$ '.

$n=\frac{48}{5.8}=8.27$

Besarnya sampel yang diperoleh dengan menggunakan persamaan (4) adalah 8.27 atau 8 sampel,namun lebih baik sampel diambil lebih dari 8.Jadi, disini diambil 12 sampel.

\subsection{Objek Penelitian}

Adapun Sekolah Menengah Pertama yang dijadikan objek penelitian yaitu:

Tabel 1. Daftar SMP yang dijadikan Objek peneltian

\begin{tabular}{|lc|}
\hline Kode & Nama Sekolah \\
\hline SS1 $)$ & SMP Negeri 1 Tahuna \\
\hline SS2) & SMP Negeri 2 Tahuna \\
\hline SS3) & SMP Negeri 3 Tahuna \\
\hline SS4) & SMP Negeri 1 Manganitu Selatan \\
\hline SS5) & SMP Negeri 1 Tabukan Selatan \\
\hline SS6) & SMP Negeri 1 Tabukan Selatan Tengah \\
\hline SS7) & SMP Negeri 1 Tabukan Selatan Tenggara \\
\hline SS8) & SMP Kristen Bellae \\
\hline SS9) & SMP Negeri 6 Tabukan Utara \\
\hline (SS10) & SMP Kristen Sawang Jauh \\
\hline (SS11) & SMP Negeri 6 Satap Manganitu \\
\hline (SS12) & SMP Negeri 4 Tamako \\
\hline
\end{tabular}




\subsection{Peubah Penelitian}

Peubah yang diamati yaitu sebagai berikut:

Tabel 2. Standar Pendidikan dan Tenaga Kependidikan (X1)

\begin{tabular}{|ll|}
\hline \multicolumn{1}{|c|}{ Kode } & \multicolumn{1}{c|}{ Definisi } \\
\hline X1a & ju mlah dan kualifikasi guru \\
\hline X1b & ju mlah dan kualifikasi tenaga admin istrasi \\
\hline X1c & ju mlah dan kualifikasi pustakawan \\
\hline X1d & ju mlah dan kualifikasi laboran \\
\hline X1e & ju mlah dan kualifikasi tenaga kebersihan \\
\hline
\end{tabular}

Tabel 3. Standar Sarana dan Prasarana (X2)

\begin{tabular}{|c|c|}
\hline Kode & Definisi \\
\hline $\mathbf{X} 2 \mathbf{a}$ & luas lahan \\
\hline $\mathbf{X} 2 \mathbf{b}$ & ju mlah dan luas ruang kelas \\
\hline $\mathrm{X} 2 \mathrm{c}$ & ju mlah dan luas ruang perpustakaan \\
\hline $\mathbf{X 2 d}$ & ju mlah buku dalam ruang perpustakaan \\
\hline $\mathrm{X} 2 \mathrm{e}$ & ju mlah dan luas laboratorium IPA \\
\hline X2f & jumlah dan luas laboratorium computer \\
\hline $\mathrm{X} 2 \mathrm{~g}$ & ju mlah co mputer \\
\hline $\mathbf{X 2 h}$ & ju mlah dan luas ruang pimpinan \\
\hline $\mathbf{X 2 i}$ & ju mlah dan luas ruang guru \\
\hline $\mathbf{X} \mathbf{2 j}$ & ju mlah dan luas ruang tata usaha \\
\hline $\mathbf{X} 2 k$ & ju mlah dan luas ruang UKS \\
\hline X21 & ju mlah dan luas ruang organisasi kesis waaan \\
\hline $\mathrm{X} 2 \mathrm{~m}$ & jumlah dan luas WC \\
\hline $\mathbf{X 2 n}$ & ju mlah OHP/LCD \\
\hline X2o & bes arnya daya lis trik \\
\hline $\mathbf{X} 2 \mathbf{p}$ & ju mlah dan luas tempat ibadah \\
\hline
\end{tabular}

Tabel 4. Standar Pengelolaan (X3)

\begin{tabular}{|ll|}
\hline \multicolumn{1}{|c|}{ Kode } & \multicolumn{1}{c|}{ Definisi } \\
\hline X3a & Pengelolaan Untuk Perencanaan Program \\
\hline X3b & Pengelolaan untuk pelaksanaan rencana sekolah \\
\hline X3c & pengelolaan untuk pengawasan dan evaluasi \\
\hline
\end{tabular}

Tabel 5. Standar Pembiayaan Pendidikan (X4)

\begin{tabular}{|ll|}
\hline Kode & \multicolumn{1}{c|}{ Definisi } \\
\hline X4a & biaya untuk bahan atau peralatan pendidikan habis pakai \\
\hline X4b & $\begin{array}{l}\text { biaya operasi pendidikan tak langsung (air,telepon pemeliharaan sarana dan } \\
\text { prasarana, uang lembur, dan transportasi). }\end{array}$ \\
\hline
\end{tabular}

\subsection{Metode Analis is}

Metode analisis yang dilakukan dengan analisis biplot dengan langkah- langkah sebagai berikut :

1. Pemasukan data (matriks data $\mathrm{X}$ ).

2. Standarisasi Matriks X (Minitab 14).

3. Penguraian matriks $X$ yang telah distandarisasi dengan SVD.

4. Penghitungan matriks $\mathrm{H}=\mathrm{AL}$ dan $\mathrm{G}=\mathrm{UL}$.

5. Plot matriks $\mathrm{G}$ dan $\mathrm{H}$ secara tumpang tindih.

Langkah 1 dan 2 dilakukan dengan menggunakan perangkat lunak Minitab 14, sedangkan langkah 3-5 dilakukan dengan menggunakan perangkat lunak SAS (Statistical Analysis Sistem). 


\section{Hasil dan Pembahasan}

Hanya dua peubah yang digunakan dalam analisis biplot yaitu peubah Standar Pendidik dan Tenaga Kependidikan serta peubah Standar Sarana dan Prasarana. Sedangkan dua peubah yang lain yaitu peubah standar pengelolaan dan peubah standar pembiayaan pendidikan, tidak digunakan da lam analisis biplot karena nilai dari kedua standar tersebut sama untuk semua SMP yang dijadikan sampel. Jadi SMP- SMP yang ada di Kabupaten Kepulauan Sangihe tidak beragam pada kedua peubah tersebut atau bisa dikatakan bahwa tingkat keragamannya mendekati nol.

Setelah menjalankan program makro biplot dan input data melalui perangkat lunak SAS 9.1.3, maka diperoleh tampilan sebagai berikut.

\subsection{Plot antara Peubah Standar Pendidik dan Tenaga Kependidikan dengan Objek Pengamatan}

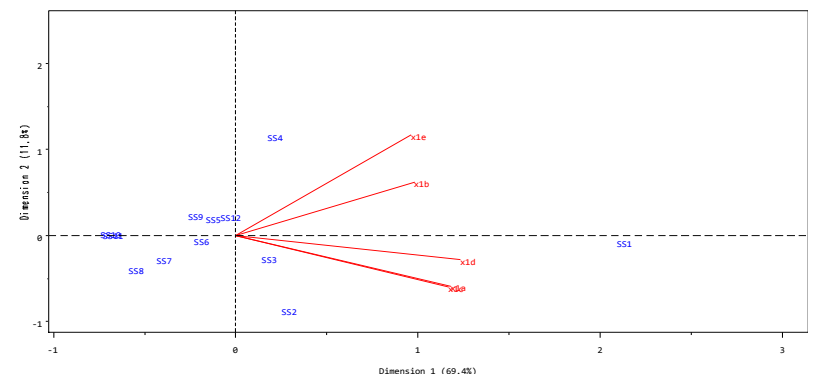

Gambar 1. Plot antara peubah X1 dengan objek pengamatan

Berdasarkan gambar 1 dapat dilihat bahwa keragaman yang diterangkan oleh dimensi 1 sebesar $69.4 \%$ dan dimensi 2 sebesar $21.8 \%$ sehing ga total keragaman sebesar $81.12 \%$. rasio skala yang digunakan dalam biplot adalah 1 . Keragaman pada peubah standar pendidik dan tenaga kependidikan yaitu pada jumlah dan kualifikasi guru (X1a), jumlah dan kualifikasi pustakawan (X1c), dan jumlah dan kualifikasi laboran(X1d) karena ketiga peubah tersebut memiliki vektor yang lebih panjang dibanding 2 vektor yang lain. Hal ini menunjukan bahwa jumlah dan kualifikasi guru (X1a), jumlah dan kualifikasi pustakawan(X1c), serta jumlah dan kualifikasi laboran(X1d) sangat beragam di SMP-SMP yang ada di Kabupaten Kepulauan Sangihe.

Dengan menggunakan persamaan (5) diperoleh nilai $\rho=0.62$, dengan nilai akar ciri terbesar pertama 6.18 ,akar ciri terbesar kedua 2.54 dari nilai $\rho$ yang telah dihitung dapat dijelaskan bahwa sebesar 0.62 atau 0.6 keakuratan dari biplot dalam menerangkan tingkat keragaman dari matriks data asal memberikan penyajian yang cukup baik.

Berdasarkan gambar 1 juga dapat dijelaskan bahwa kedekatan antar objek ditunjukan oleh SMP Negeri 1 Tabukan Selatan (SS5), SMP Negeri 6 Tabukan Utara (SS9) dan SMP Negeri 4 Tamako (SS12) karena jarak ketiga objek yang berdekatan. Hal ini menunjukan bahwa karakteristik standar tenaga pendidik dan tenaga kependidikan ketiga objek tersebut relatif sama. Sama halnya dengan SMP Kristen Sawang Jauh (SS10) dan SMP Negeri 6 Satap Manganitu (SS11).

Pada biplot terlihat bahwa SMP Negeri 1 Tahuna (SS1) unggul pada jumlah dan kualifikasi guru (X1a), jumlah dan kualifikasi pustakawan(X1c), dan juga jumlah dan kualifikasi laboran(X1d) karena vektor ketiga peubah tersebut searah dengan objek SS1.

Gambar 1 juga menunjukan objek-objek yang terbagi pada kedua sisi dimensi 2 namun tidak satupun vektor peubah yang mengarah ke objek- objek disebelah kiri dimensi 2 .Hal ini berarti sekolah-sekolah yang terletak disebelah kiri dimensi 2 itu memiliki standar yang kurang baik terhadap peubah standar pendidik dan tenaga kependidikan(X1).Sedangkan sekolah- sekolah yang terletak disisi kanan dimensi 2 merupakan sekolah dengan mutu yang baik terhadap peubah standar tenaga pendidik dan tenaga kependidikan. 


\subsection{Plot antara Peubah Standar Sarana dan Prasarana dengan Objek Pengamatan}

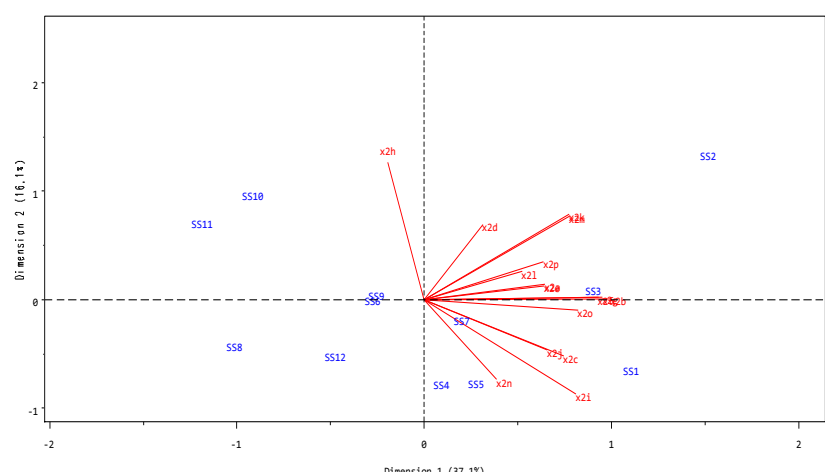

Gambar 2. Plot antara peubah X2 dengan objek pengamatan

Berdasarkan gambar 2 dapat dilihat bahwa keragaman yang diterangkan oleh dimensi 1 sebesar $37.1 \%$ dan dimensi 2 sebesar $16.1 \%$ sehingga total keragaman sebesar 53.20\%. Rasio skala yang digunakan dalam biplot adalah 1.Keragaman pada peubah standar sarana dan prasarana yaitu pada jumlah komputer $(\mathrm{X} 2 \mathrm{~g})$, jumlah dan luas ruang pimpinan $(\mathrm{X} 2 \mathrm{~h})$, jumlah dan luas ruang guru (X2i), jumlah dan luas ruang uks (X2k), jumlah dan luas WC (X2m) karena kelima peubah tersebut memiliki vektor yang lebih panjang dibanding vektor - vektor yang lain. Hal ini menunjukan bahwa jumlah komputer (X2g), jumlah dan luas ruang pimpinan (X2h), jumlah dan luas ruang guru (X2i), jumlah dan luas ruang uks (X2k), jumlah dan luas WC (X2m) sangat beragam di SMP-SMP yang ada di Kabupaten Kepulauan Sangihe.

Dengan menggunakan persamaan (5) diperoleh nilai $\rho=0.36$, dengan nilai akar ciri terbesar pertama 8.08,akar ciri terbesar kedua 5.32, dari nilai $\rho$ yang telah dihitung dapat dijelaskan bahwa sebesar 0.36 atau 0.4 keakuratan dari biplot dalam menerangkan tingkat keragaman dari matriks data asal memberikan penyajian yang cukup baik.

Berdasarkan gambar 2 juga dapat dije laskan bahwa kedekatan antar objek ditunjukan oleh SMP Negeri 1 Tabukan Selatan Tengah (SS6) dan SMP Negeri 6 Tabukan Utara (SS9) karena jarak kedua objek yang berdekatan. Hal ini menunjukan bahwa karakteristik standar sarana dan prasarana kedua objek tersebut relatif sama. Sama halnya dengan SMP Kristen Sawang Jauh (SS10) dan SMP Negeri 6 Satap Manganitu (SS11).Begitu juga dengan SMP Negeri 1 Manganitu Selatan (SS4), dan SMP Negeri 1 Tabukan Selatan (SS5).

Pada biplot terlihat bahwa SMP Negeri 1 Tahuna (SS1) unggul pada jumlah dan luas ruang perpustakaan (X2c), jumlah dan luas ruang guru (X2i), serta jumlah dan luas ruang tata usaha (X2j) karena vektor ketiga peubah tersebut searah dengan objek SS1. Begitu juga dengan SMP Negeri 3 Tahuna (SS3) terlihat unggul pada jumlah dan luas ruang kelas (X2b), jumlah dan luas laboratorium computer (X2f), dan jumlah komputer (X2g).

Pada gambar 2 juga terlihat bahwa ada beberapa objek yang terletak tidak searah dengan vektor- vektor yang ada. Hal ini berarti objek- objek tersebut memiliki standar sarana dan prasarana yang kurang baik, objek- objek tersebut yaitu SMP Negeri 1 Tabukan Selatan Tengah (SS6), SMP Negeri 6 Tabukan Utara (SS9), SMP Kristen Bellae(SS8), SMP Kristen Sawang Jauh (SS10), SMP Negeri 6 Satap Manganitu (SS11) dan SMP Negeri 4 Tamako (SS12). 


\subsection{Plot antara 2 peubah (peubah pendidik dan tenaga kependidikan danPeubah Standar Sarana dan Prasarana) dengan Objek Pengamatan}

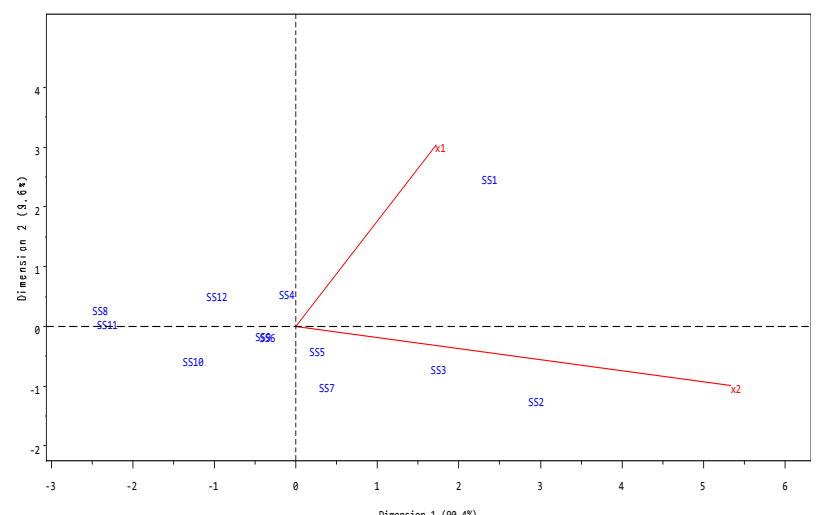

Gambar 3. Plot antara 2 peubah dengan Objek pengamatan

Berdasarkan gambar 3 dapat dilihat bahwa keragaman yang diterangkan oleh dimensi 1 sebesar $90.4 \%$ dan dimensi 2 sebesar $9.6 \%$ sehing ga total keragaman sebesar $100 \%$. rasio skala yang digunakan dalam biplot adalah 1. peubah standar sarana dan prasarana(X2) memiliki keragaman yang besar karena memiliki vektor yang panjang. Hal ini menunjukkan bahwa SMPSMP yang ada di Kabupaten Kepulauan Sangihe sangat beragam dalam peubah standar sarana dan prasarana.

Dengan menggunakan persamaan (5) diperoleh nilai $\rho=1$, dengan nilai akar ciri terbesar pertama 6.29 ,akar ciri terbesar kedua 2.05, dari nilai $\rho$ yang telah dihitung dapat dijelaskan bahwa keakuratan dari biplot dalam menerangkan tingkat keragaman dari matriks data asal memberikan penyajian yang sangat baik.

Berdasarkan gambar 3 juga dapat dijelaskan bahwa kedekatan antar objek ditunjukan oleh SMP Negeri 1 Tabukan Selatan Tengah(SS6) dan SMP Negeri 6 Tabukan Utara(SS9) karena jarak kedua objek yang berdekatan. Hal ini menunjukan bahwa karakteristik standar tenaga pendidik dan tenaga kependidikan dan juga standar sarana dan prasarana kedua objek tersebut relatif sama. Sama halnya dengan SMP Negeri 6 Satap Manganitu (SS11) dan SMP Kristen Bellae(SS8).

Pada biplot terlihat bahwa SMP Negeri 1 Tahuna (SS1) unggul pada peubah standar pendidik dan tenaga kependidikan karena vektor peubah tersebut searah dengan objek SS1. Dan juga SMP Negeri 3 Tahuna(SS3) bisa dikatakan unggul pada peubah standar sarana dan prasarana.

Gambar 3 juga menunjukan objek-objek yang terbagi pada kedua sisi dimensi 2 namun tidak satupun vektor peubah yang mengarah ke objek- objek disebelah kiri dimensi 2.Hal ini berarti objek-objek yang terletak disebelah kiri dimensi 2 itu memiliki standar yang kurang baik terhadap peubah standar tenaga pendidik dan tenaga kependidikan(X1) dan juga standar sarana dan prasarana(X2). Objek - objek tersebut yaitu SMP Negeri 1 Manganitu Selatan, SMP Negeri 1 Tabukan Selatan Tengah, SMP Kristen Bellae, SMP Negeri 6 Tabukan Utara, SMP Kristen Sawang Jauh, SMP Negeri 6 Satap Manganitu, SMP Negeri 4 Tamako. Sedangkan objek- objek yang terletak disisi kanan dimensi 2 merupakan sekolah dengan mutu yang baik terhadap peubah standar tenaga pendidik dan tenaga kependidikan dan juga standar sarana dan prasarana.

\section{Kesimpulan}

Berdasarkan hasil dan pembahasan yang ada, dapat disimpulkan bahwa:

Berdasarkan plot peubah standar pendidik dan tenaga kependidikan, SMP Neegeri 1 Tahuna merupakan sekolah yang unggul pada jumlah dan kualifikasi guru, jumlah dan kualifikasi pustakawan dan jumlah dan kualifikasi laboran.Berdasarkan plot peubah standar sarana dan prasarana, bahwa SMP Negeri 1 Tahuna merupakan sekolah yang unggul pada jumlah dan luas ruang perpustakaan, jumlah dan luas ruang guru, serta jumlah dan luas ruang tata usaha. SMP Negeri 3 Tahuna terlihat unggul pada jumlah dan luas ruang kelas, jumlah dan luas laboratorium komputer, dan jumlah komputer.Berdasarkan plot antara 2 peubah (standar pendidik dan tenaga kependidikan, dan standar sarana dan prasarana) dengan objek pengamatan, sekolah- sekolah yang dikategorikan memiliki keunggulan terhadap dua indikator standar nasional pendidikan adalah 
SMP Negeri 1 Tahuna, SMP Negeri 2 Tahuna, SMP Negeri 3 Tahuna, SMP Negeri 1 Tabukan Selatan tenggara dan SMP Negeri 1 Tabukan Selatan. Sedangkan Sekolah - sekolah yang laindikategorikan memiliki standar yang kurang unggul terhadap dua indikator standar nasional pendidikan. Peubah standar pengelolaan dan standar pembiayaan pendidik mempunyai keragaman yang mendekati nol.

\section{Daftar Pustaka}

[1] Daman. R., D.Hatidja. 2012. Pemetaan SMP- SMP di Kabupaten Minahasa Tenggara, Sulawesi Utara berdasarkan Standar Pendidikan dan Tenaga Kependidikan, Standar Sarana dan Prasarana, Standar Pengelolaan dan Standar Pembiayaan Pendidikan dengan Menggunakan Analis is Biplot. D'Cartesian. Vol 1 No. 1.

[2] Everit, B. 1978. Graphical Techniques for Multivariate Data. Heinermann Educational Books.

[3] Joliffe, I.T. 1986. Principal Component Analysis.Springer. Verlag. New York.

[4] Mattjik,A.A. M.Sumertajaya, Wijayanto, Indahwati.A, Kurnia.B, Sartono. 2004. Modul Teori Pelatihan Analis is Multivariat. Departemen Statistika FMIPA IPB, Bogor.

[5] Siregar, Syofian. 2010. Statistika Deskriptif untuk penelitian dilengkapi perhitungan manual dan Aplikasi SAS Versi 17. PT. Raja Grafindo Persada, Jakarta. 